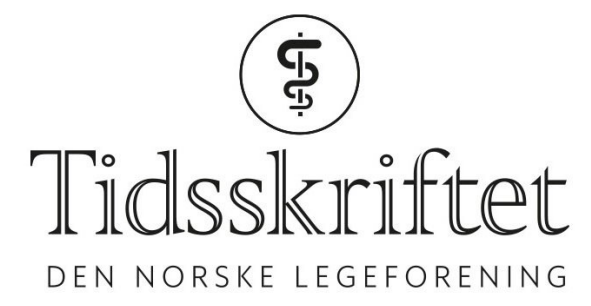

\title{
Flere virkemåter for cannabis
}

FRA ANDRE TIDSSKRIFTER

HAAKON B. BENESTAD

Universitetet i Oslo

Cannabis hemmer sosiale aktiviteter hos mus ved å redusere laktatproduksjonen i astrocytter og dermed energitilførselen til nærliggende nevroner.

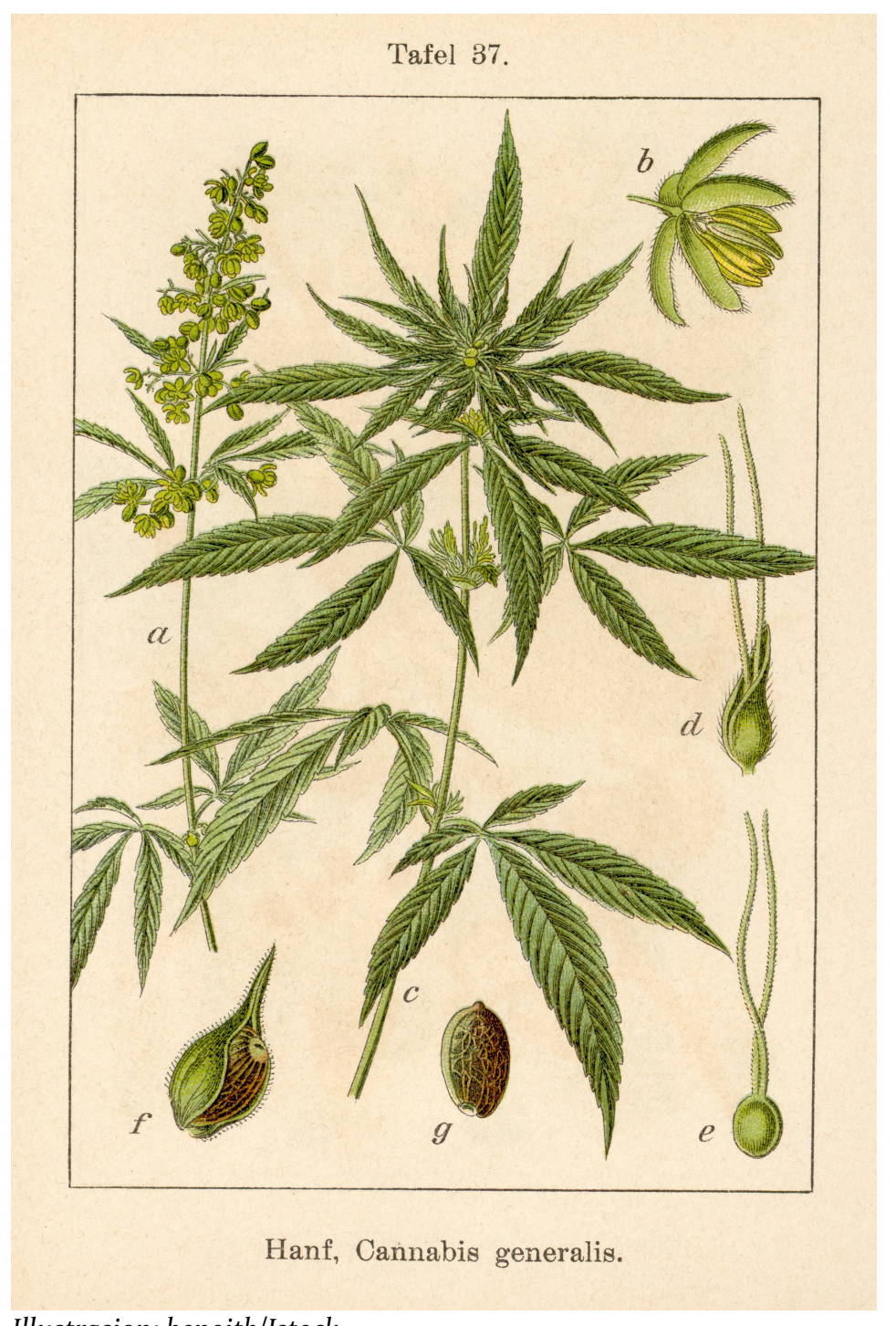

Illustrasjon: benoitb/Istock

Psykotrope stoffer og mange legemidler virker på samspillet mellom hjernens 
nevrotransmittere og deres reseptorer. Denne mekanismen antas å forklare virkningen av cannabinoider, som er virkestoffer i marihuana. En ny musestudie tyder på at virkeligheten er mer kompleks: Den viktige psykoaktive komponenten tetrahydrocannabinol griper inn i laktatmetabolismen i astrocytter og påvirker derfra nærliggende nevroner (1).

Komponenter i den oksidative fosforyleringen lekker normalt reaktive oksygenderivater fra mitokondriene, spesielt i astrocytter. Derivatene stimulerer glykolysen og dermed laktatdannelse. Laktatet diffunderer ut av astrocyttene og fraktes inn i nabonevroner. Her har laktat en positiv rolle i energiproduksjonen og samtidig nevronets funksjon. Tetrahydrocannabinol kan forstyrre denne mekanismen. Dette ble bl.a. vist ved å dyrke nevroner sammen med tetrahydrocannabinol-behandlede astrocytter.

Tetrahydrocannabinol bandt seg til en mitokondriell cannabinoidreseptor i astrocyttene og reduserte laktatdannelsen via en signalkaskade. Som et resultat av dette ble laktatimporten til nevronene hemmet, og nevronene ble stresset så sterkt at noen gikk i apoptose.

Aktiviteten i nervenettverket i hippocampus og prefrontalkorteks som nevronene er en del av, ble redusert. Denne svekkelsen kom også til uttrykk ved at musenes sosiale aktivitet ble redusert. In vitro- og in vivo-tilførsel av laktat opphevet svekkelsen, og forsøk med genredigerte mus bekreftet funnene.

- Disse forsøkene føyer seg til andre studier som viser at laktat har en signalfunksjon i hjernen, sier Linda Hildegard Bergersen, som er professor i fysiologi ved Universitetet i Oslo.

- Dette er komplekst. Laktat virker gjennom flere mekanismer. Én mekanisme er at en Gprotein-koplet reseptor formidler noe av effekten fysisk aktivitet har på hjernen. Disse forskerne refererer til våre studier der dette ble påvist, men de finner ikke at nettverkseffektene av tetrahydrocannabinol går gjennom denne laktatreseptoren. Imidlertid viser andres og våre upubliserte funn at den aktuelle laktatreseptoren regulerer nevronnettverkaktivitet, selv om cannabinoidreseptoren ikke er vist på en overbevisende måte, sier Bergersen.

LITTERATUR:

1. Jimenez-Blasco D, Busquets-Garcia A, Hebert-Chatelain E et al. Glucose metabolism links astroglial mitochondria to cannabinoid effects. Nature 2020; 583: 603-8. [PubMed][CrossRef]

Publisert: 6. januar 2021. Tidsskr Nor Legeforen. DOI: 10.4045/tidsskr.20.089o

(C) Tidsskrift for Den norske legeforening 2020. Lastet ned fra tidsskriftet.no 